\title{
The Tricarboxylic Acid Cycle of Heterogeneous and Swarmer Cell Populations of Rhodomicrobium vannielii Rm5
}

\author{
By PHILIP MORGAN, DAVID J. KELLY AND CRAWFORD S. DOW* \\ Department of Biological Sciences, University of Warwick, Coventry CV4 7AL, UK
}

(Received 16 August 1985; revised I November 1985)

\begin{abstract}
Studies on the tricarboxylic acid cycle of Rhodomicrobium vannielii $\mathrm{Rm} 5$ demonstrated that, unlike other Rhodospirillaceae, this organism has a functionally incomplete cycle, broken at 2oxoglutarate dehydrogenase, under photoheterotrophic conditions. This enzyme was, however, synthesized when $R m$. vannielii was grown under microaerophilic chemoheterotrophic conditions. The citrate synthase exhibited responses to inhibitors characteristic of Gramnegative organisms but, unlike many microbes exhibiting an incomplete cycle, was not inhibited by 2-oxoglutarate. Both NAD- and NADP-linked isocitrate dehydrogenase activity was detectable but the functional roles of these enzymes are unclear. No significant differences in enzyme activities or inhibitor sensitivities of enzymes were detected between heterogeneous cultures and synchronous swarmer cell populations.
\end{abstract}

\section{INTRODUCTION}

Rhodomicrobium vannielii (Duchow \& Douglas, 1949) is a member of the Rhodospirillaceae in which cell growth is polar and cell division asymmetric (Whittenbury \& Dow, 1977; Kelly \& Dow, 1984). Batch cultures of this photoheterotroph contain several morphologically distinct cell types with the characteristic cellular expression consisting of multicellular arrays of cells linked by prosthecae from the tips of which ovoid, peritrichously flagellated swarmer cells are produced (Whittenbury \& Dow, 1977). A particularly interesting feature of this microbe is the variety of alternative cellular expressions possible under different environmental conditions. For example, high partial pressures of $\mathrm{CO}_{2}$ coupled with low light intensities during growth can induce a simplified vegetative cell cycle where swarmer cells are produced constitutively (Dow \& France, 1980). Alternatively, exhaustion of nutrients in batch cultures or growth on poor carbon sources can lead to the production of heat-resistant, angular exospores (Whittenbury \& Dow, 1977; Potts \& Dow, 1979).

As part of our investigations into cellular morphogenesis in $R m$. vannielii we have focused attention upon the nature of the swarmer cell and the control of differentiation. Synchronized swarmer cell populations can be obtained quickly and in quantity by filtration of a heterogeneous, asynchronous batch culture through glass wool (Whittenbury \& Dow, 1977) and, when incubated anaerobically in the light, these cells undergo an obligate sequence of events leading to the formation of a daughter cell. These events have been well characterized and include nucleoid relaxation, flagella loss and prostheca synthesis as the major morphological 'landmarks' in addition to a temporal programme of protein synthesis (Whittenbury \& Dow, 1977; Dow et al., 1983).

A necessary prerequisite for a greater understanding of the swarmer cell is a knowledge of the pathways of intermediary metabolism. There is little information in the literature concerning the metabolism of swarmer cells and we therefore chose to study the role of the tricarboxylic acid (TCA) cycle in the provision of cellular intermediates. This is of particular interest in view of the apparent metabolic quiescence of the swarmer cell with regard to transcription and translation.

Abbreviation: TCA, tricarboxylic acid. 


\section{METHODS}

Organisms and culture conditions. Rhodomicrobium vannielii $\mathrm{Rm} 5$ was grown photoheterotrophically at $30^{\circ} \mathrm{C}$ in pyruvate/malate/mineral salts (PM) medium (Whittenbury \& Dow, 1977) under an atmosphere of oxygen-free nitrogen and with a light intensity of $1000 \mathrm{~lx}$. Cultures were continuously stirred. Microaerophilic cultures were grown in 2-litre volumes of PM medium in 2.5-litre conical flasks in darkness at $30^{\circ} \mathrm{C}$ on a rotary shaker $(175$ r.p.m.). Escherichia coli $\mathrm{C}$ and Pseudomonas putida were grown aerobically at $30^{\circ} \mathrm{C}$ in $\mathrm{M} 9$ mineral salts medium (Lark et al., 1963) containing $0.02 \%(w / v)$ glucose or sodium acetate. Growth was followed by measuring optical density at $600 \mathrm{~nm}$ and by total cell counts obtained using a Coulter counter model ZBI.

Radiolabelling experiments. $R m$. vannielii was grown as described above in $100 \mathrm{ml}$ batches of PM medium containing $1 \mu \mathrm{Ci}$ sodium [U.-14 C] acetate $\mathrm{ml}^{-1}$ (specific activity $59 \mathrm{mCi} \mathrm{mmol}^{-1} ; 2183 \mathrm{MBq} \mathrm{mmol}^{-1}$ ).

Synchronization of $R m$. vannielii. Cultures (10 litres) of $R m$. vannielii in the late exponential phase $\left(\mathrm{OD}_{600} 1 \cdot 2\right)$ of growth were synchronized by passage through glass wool filled columns as described by Whittenbury \& Dow (1977). The degree of synchrony was determined by light microscopy and by particle volume distribution analysis using a Coulter counter ZBI-C1000 channelyzer system linked to an Acorn BBC model B microcomputer. The effluent from the columns was maintained in darkness to prevent cellular differentiation and concentrated to a volume of approximately $500 \mathrm{ml}$ by a Millipore Pellicon ultrafiltration system.

Hydrolysis of cellular protein. Portions of radiolabelled late exponential phase cultures of $R m$. vannielii were added to equal volumes of $10 \%(\mathrm{w} / \mathrm{v})$ trichloroacetic acid and incubated at $4{ }^{\circ} \mathrm{C}$ for $30 \mathrm{~min}$. Trichloroacetic acid precipitable material was pelleted by centrifugation at $15000 \mathrm{~g}$ and $4{ }^{\circ} \mathrm{C}$ for $15 \mathrm{~min}$. The pellet was resuspended in $70 \%(\mathrm{v} / \mathrm{v})$ ethanol, incubated at $45^{\circ} \mathrm{C}$ for $30 \mathrm{~min}$ and the precipitate pelleted as described above. The pellet was resuspended in diethyl ether/ethanol $(1: 1, \mathrm{v} / \mathrm{v})$, incubated at $30^{\circ} \mathrm{C}$ for $45 \mathrm{~min}$ and centrifuged as described above. The pellet was resuspended in $5 \%(\mathrm{w} / \mathrm{v})$ trichloroacetic acid and incubated at $95^{\circ} \mathrm{C}$ for $30 \mathrm{~min}$. After centrifugation as described above, the precipitate was washed three times with ethanol and resuspended in $5 \mathrm{ml}$ $6 \mathrm{M}-\mathrm{HCl}$. The suspension was sealed in hydrolysis tubes and incubated at $105^{\circ} \mathrm{C}$ for $18 \mathrm{~h}$.

Disruption of cells. Cells were harvested from 5-litre $(R m$. vannielii) or 1-litre (E. coli and $P$. putida) cultures, or from synchronous $R m$. vannielii swarmer cell concentrates, by centrifugation at $14000 \mathrm{~g}$ and $4{ }^{\circ} \mathrm{C}$ for $10 \mathrm{~min}$. Cell pellets were washed twice in sterile medium and resuspended in approximately $20 \mathrm{ml}$ sterile $10 \mathrm{mM}-\mathrm{Tris} / \mathrm{HCl}$ buffer ( $\mathrm{pH} \mathrm{7.0)}$ ). Two methods of disruption were used: ultrasonication using a MSE 12/76 mark II ultrasonicator with a peak wavelength of $10-12 \mu \mathrm{m}$ in $15 \mathrm{~s}$ pulses (cumulative sonication time $150 \mathrm{~s}$ ) with the sample cooled in a bath of methanol-ice; disruption by French pressure cell involving two passages at $4^{\circ} \mathrm{C}$ at a pressure of $137 \mathrm{MPa}$. Unbroken cells and cell debris were removed by centrifugation at $18000 \mathrm{~g}$ and $4{ }^{\circ} \mathrm{C}$ for $45 \mathrm{~min}$.

Two-dimensional chromatography. Samples (10 and $25 \mu \mathrm{l}, 10^{4}-2 \times 10^{5}$ c.p.m.) of $\mathrm{Rm}$. vannielii protein hydrolysates were separated by two-dimensional paper chromatography on Whatman no. 1 chromatography paper. The solvent system for the first dimension was butanol/acetic acid/water $(180: 45: 75$, by vol.; run-time $16 \mathrm{~h})$ and for the second dimension $80 \%(w / v)$ aqueous phenol/aqueous ammonia $(300: 1 \cdot 5, \mathrm{v} / \mathrm{v} ;$ run-time $15 \mathrm{~h})$. Chromatograms were air dried and developed by spraying with $0.25 \%(\mathrm{w} / \mathrm{v})$ ninhydrin dissolved in acetone followed by heating at $100^{\circ} \mathrm{C}$. Amino acid spots were identified by comparison with chromatograms of known amino acid standards.

Enzyme assay methods. Citrate synthase [citrate oxaloacetate-lyase (CoA acetylating); EC 4.1.3.7], isocitrate dehydrogenase $\left[\mathrm{L}_{\mathrm{s}}\right.$-isocitrate: $\mathrm{NADP}^{+}$oxidoreductase (decarboxylating); EC 1.1.1.42 and $\mathrm{L}_{\mathrm{s}}$-isocitrate : $\mathrm{NAD}^{+}$ oxidoreductase (decarboxylating); EC 1.1.1.41], malate dehydrogenase (L-malate: NAD $^{+}$oxidoreductase; EC 1.1.1.37) and fumarase (L-malate hydro-lyase; EC 4.2.1.2) were assayed spectrophotometrically according to the methods of Reeves et al. (1971). Inhibitors of citrate synthase were added directly to the assay system which contained ( $\mu \mathrm{mol}$ in $3 \mathrm{ml})$ : Tris/ $\mathrm{HCl}(\mathrm{pH} 8 \cdot 1), 600$; potassium oxaloacetate, $1 \cdot 5$; acetyl-CoA, $0 \cdot 3 ; 5,5^{\prime}$-dithiobis(2nitrobenzoate), $0 \cdot 6$.

The 2-oxoglutarate dehydrogenase enzyme system was assayed by a modification of the method of Reeves $e t$ al. (1971). The system contained ( $\mu \mathrm{mol}$ in $3 \mathrm{ml}$ ): Tris/ $\mathrm{HCl}(\mathrm{pH} \mathrm{8.5),} \mathrm{500;} \mathrm{L-cysteine,} \mathrm{7.8;} \mathrm{potassium} \mathrm{2-oxoglutarate,}$ 25; Coenzyme A, $0 \cdot 25$; NAD, 6; potassium cyanide, 10; plus a variable volume of cell lysate. The reaction was started by the addition of $\mathrm{NAD}^{+}$and followed by measuring the 2-oxoglutarate-dependent reduction of $\mathrm{NAD}^{+}$at $340 \mathrm{~nm}$.

Aconitase [citrate(isocitrate) hydro-lyase; EC 4.2.1.3] was assayed spectrophotometrically in a system containing ( $\mu \mathrm{mol}$ in $3 \mathrm{ml}$ ): manganese chloride, 6 ; Tris/ $\mathrm{HCl}$ ( $\mathrm{pH} \mathrm{7.5),300;} \mathrm{sodium} \mathrm{cis-aconitate,} \mathrm{15;} \mathrm{NADP+1.5;}$ isocitrate dehydrogenase, 1 unit; plus a variable volume of cell lysate. The reaction was started by the addition of cis-aconitate and followed at $340 \mathrm{~nm}$, by measuring the reduction of NADP+ by the action of isocitrate dehydrogenase utilizing isocitrate produced from cis-aconitate by the action of aconitase.

Succinate thiokinase [succinate-CoA ligase (ADP-forming); EC 6.2.1.5] was assayed by coupling the reverse reaction of the enzyme through pyruvate kinase and lactate dehydrogenase as described by Cha (1969).

Succinate dehydrogenase [succinate:(acceptor) oxidoreductase; EC 1.3.99.1] was assayed by spectrophotometrically measuring at $600 \mathrm{~nm}$ the reduction of 2,6-dichlorophenolindophenol mediated by phenazine 
methosulphate using a method modified from that of King (1963). The system contained ( $\mu \mathrm{mol}$ in $3 \mathrm{ml}$ ): potassium phosphate buffer ( $\mathrm{pH} 7.6$ ), 150; 2,6-dichlorophenolindophenol, $0 \cdot 18$; phenazine methosulphate, $1 \cdot 2$; sodium succinate, 20; potassium cyanide, 7; plus a variable volume of cell lysate. The reaction was started by the addition of succinate.

Protein concentrations were assayed by the Lowry method as described by Herbert et al. (1971) using bovine serum albumin standards.

Conversion of 2-oxoglutarate by cell-free extracts. Cell-free extracts of $R m$. vannielii and $E$. coli were incubated at $30^{\circ} \mathrm{C}$ for up to $2 \mathrm{~h}$ in the presence of the reagents described above for the 2-oxoglutarate dehydrogenase assay (omitting potassium cyanide) plus $0.1 \mu \mathrm{Ci}$ sodium $2-0 x 0\left[5-{ }^{-14} \mathrm{C}\right]$ glutarate $\mathrm{ml}^{-1}$. Samples were taken at regular intervals and the reaction was stopped by freezing in liquid nitrogen. Separation of organic acids, after thawing of the frozen samples on ice, was by one-dimensional paper chromatography (Whatman no. 1 paper) of $50 \mu \mathrm{l}$ samples using a solvent system of butanol/acetic acid/water $(60: 15: 25$, by vol.) and a run-time of $5 \mathrm{~h}$. Standard organic acids were visualized by immersing the paper in $0.1 \%(w / v)$ bromophenol blue $+0.1 \%(w / v)$ methyl red in $95 \%$ $(\mathrm{v} / \mathrm{v})$ ethanol and appeared as yellow spots on a blue background.

Determination of radioactivity. Ninhydrin-stained amino acid spots from two-dimensional chromatograms and sequential $1 \mathrm{~cm}$ bands from one-dimensional chromatograms were cut out and placed in Beckman EP scintillation fluid. Liquid scintillation counting was done with an LKB 1212 Minibeta counter.

Autoradiography. Kodak Kodirex X-ray film was exposed to two-dimensional chromatograms for 2 weeks and developed using Kodak LX-24 developer followed by Kodak FX-40 fixer. Exposed areas of the film were cut out and quantified by the silver grain elution technique described by Suissa (1983). The film areas were incubated for $2 \mathrm{~h}$ in $1 \mathrm{M}-\mathrm{NaOH}$ and the absorbance of the supernatants at $500 \mathrm{~nm}$ was measured against that from a piece of developed but unexposed film.

Reagents. Sodium [U-14 C]acetate and 2-oxo[5-1+ C]glutarate (sodium salt) were obtained from Amersham. Enzymes and fine biochemicals were obtained from Sigma. All other reagents were of Analar standard or the highest purity commercially available.

\section{RESULTS}

Incorporation of ${ }^{14} \mathrm{C}$ into amino acids. Two-dimensional paper chromatography of ${ }^{14} \mathrm{C}$-labelled protein hydrolysates of $\mathrm{Rm}$. vannielii yielded clear separation of the amino acid residues which, with the exception of one spot, could be identified by comparison with the standard amino acid mixtures. Visual examination of autoradiographs of chromatograms loaded with hydrolysates from photoheterotrophically grown cells revealed that the label predominated in the leucine group, glutamine, proline and arginine with relatively little incorporation of label elsewhere. These observations were confirmed and quantified by both liquid scintillation counting and spectrophotometric evaluation of the silver grains eluted from autoradiograms (Table 1), the aforementioned amino acids accounting for about $70 \%$ of the total recoverable radioactivity or total silver grain absorbance.

\section{Table 1. Incorporation of radiolabel from sodium $\left[U-{ }^{14} C\right]$ acetate into amino acids of $R m$. vannielii during photoheterotrophic or chemoheterotrophic growth}

Protein hydrolysate $\left(10 \mu \mathrm{l}, 2 \times 10^{5}\right.$ c.p.m.) was applied to the origin and chromatographed as described in Methods. Quantification was achieved after autoradiography by spectrophotometry of the eluted silver grains. Comparisons of this method with data from liquid scintillation counting of ninhydrinstained spots on the chromatograms always showed excellent agreement.

Amino acid $\overbrace{\begin{array}{c}\text { Photo- } \\ \text { heterotrophic }\end{array} \begin{array}{c}\text { Chemo- } \\ \text { silver grain absorbance }\end{array}}^{\begin{array}{c}\text { Cheme of } \\ \text { hetrophic }\end{array}}$

Aspartate

Glutamine

Cysteine + cystine

Serine

Glycine

Threonine

Alanine

Tyrosine

Valine

$\begin{array}{rrl}7.1 & 10.0 & \text { Leucine }+ \text { isoleucine }+ \\ 18.5 & 14.7 & \text { phenylalanine } \\ 0.4 & 1.0 & \text { Proline } \\ 1.8 & 1.8 & \text { Arginine } \\ 1.9 & 2.6 & \text { Methionine } \\ 3.9 & 4.7 & \text { Lysine }+ \text { histidine } \\ 1.8 & 2.7 & \text { Ornithine } \\ 2.6 & 2.4 & \text { Unknown } \\ 1.6 & 2.4 & \end{array}$

\section{Amino acid}

Percentage of total silver grain absorbance

$\overbrace{\begin{array}{c}\text { Photo- } \\ \text { heterotrophic }\end{array}}^{\begin{array}{c}\text { Chemo- } \\ \text { heterotrophic }\end{array}}$

$24 \cdot 1$

$11 \cdot 5$

$15 \cdot 2$

0.9

4.9

0.7

$2 \cdot 5$
$17 \cdot 6$

$8 \cdot 3$

$10 \cdot 3$

$0 \cdot 2$

$4 \cdot 6$

$0 \cdot 2$

$16 \cdot 5$ 
Table 2. Activities of enzymes of the TCA cycle in photoheterotrophically grown heterogeneous cultures and synchronous swarmer cell populations of $\mathrm{Rm}$. vannielii

Activities (nmol substrate converted per min by $1 \mathrm{mg}$ protein) are the means of between 3 and 7 independent experiments with at least 3 assays done in each experiment. 2-Oxoglutarate dehydrogenase

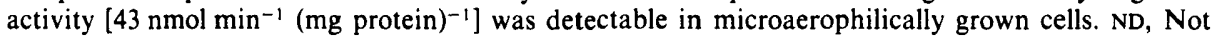
determined. For details of assay procedures see text.

\begin{tabular}{|c|c|c|}
\hline \multirow[b]{2}{*}{ Enzyme } & \multicolumn{2}{|c|}{ Activity $\left[\mathrm{nmol} \mathrm{min}{ }^{-1}(\mathrm{mg} \text { protein })^{-1}\right]$} \\
\hline & Heterogeneous culture & Swarmer cells \\
\hline Citrate synthase & $37 \cdot 1$ & $45 \cdot 2$ \\
\hline Aconitase & $43 \cdot 3$ & $40 \cdot 0$ \\
\hline \multicolumn{3}{|l|}{ Isocitrate dehydrogenase } \\
\hline NADP-linked & $242 \cdot 1$ & $229 \cdot 6$ \\
\hline NAD-linked & 74.5 & $59 \cdot 2$ \\
\hline 2-Oxoglutarate dehydrogenase & $<0.1$ & $<0.1$ \\
\hline Succinate thiokinase & 23.6 & $25 \cdot 3$ \\
\hline Succinate dehydrogenase & 75.7 & ND \\
\hline Fumarase & $10 \cdot 8$ & ND \\
\hline Malate dehydrogenase & $1835 \cdot 0$ & $1821 \cdot 0$ \\
\hline
\end{tabular}

Table 3. Effects of inhibitors on citrate synthase from heterogeneous cultures and synchronous swarmer cell populations of photoheterotrophically grown Rm. vannielii

For details of the assay system see Methods. Activities are expressed as a percentage of the control system: $100 \%$ activity corresponds to $37 \cdot 1 \mathrm{nmol} \mathrm{min}^{-1}$ (mg protein) ${ }^{-1}$. ND, Not determined.

\begin{tabular}{|c|c|c|c|}
\hline \multirow[b]{2}{*}{ Inhibitor } & \multirow{2}{*}{$\begin{array}{l}\text { Concn } \\
(\mathrm{mM})\end{array}$} & \multicolumn{2}{|c|}{ Activity (percentage of control) } \\
\hline & & Heterogeneous culture & Swarmer cells \\
\hline ATP & $\begin{array}{r}1.0 \\
2.0 \\
5 \cdot 0 \\
10.0\end{array}$ & $\begin{array}{l}98.4 \\
92.3 \\
75.0 \\
56.7\end{array}$ & $\begin{array}{l}\text { ND } \\
94 \cdot 3 \\
77 \cdot 6 \\
53 \cdot 0\end{array}$ \\
\hline ADP & $\begin{array}{r}2 \cdot 0 \\
5 \cdot 0 \\
10 \cdot 0\end{array}$ & $\begin{array}{l}98.1 \\
97 \cdot 3 \\
88.7\end{array}$ & $\begin{array}{l}\text { ND } \\
\text { ND } \\
89 \cdot 6\end{array}$ \\
\hline AMP & $10 \cdot 0$ & 99.0 & 99.8 \\
\hline NAD & $5 \cdot 0$ & $100 \cdot 1$ & $100 \cdot 3$ \\
\hline NADH & $\begin{array}{l}0.1 \\
0.5 \\
1.0 \\
2.0\end{array}$ & $\begin{array}{l}92.4 \\
53.7 \\
15.9 \\
10.8\end{array}$ & $\begin{array}{l}92.4 \\
55.6 \\
15.7 \\
11.6\end{array}$ \\
\hline $\mathrm{NADH}+\mathrm{AMP}$ & $\begin{array}{l}2+1 \\
1+1\end{array}$ & $\begin{array}{l}95 \cdot 3 \\
98 \cdot 4\end{array}$ & $\begin{array}{l}\text { ND } \\
97 \cdot 4\end{array}$ \\
\hline 2-Oxoglutarate & 10 & $101 \cdot 7$ & $103 \cdot 4$ \\
\hline
\end{tabular}

When $R m$. vannielli was grown under microaerophilic chemoheterotrophic conditions the percentage distribution of acetate-derived carbon in the amino acids of protein hydrolysates was significantly altered (Table 1). Compared to photoheterotrophically grown cells, less label was observed in glutamine, the leucine group, proline and arginine while more label was incorporated into aspartate and threonine. In addition, a large increase in the labelling of an unidentified ninhydrin-staining spot was a feature of growth under chemoheterotrophic conditions.

$T C A$ cycle enzymes of heterogeneous and synchronous populations of $R m$. vannielii. Values for enzyme activity in both late exponential phase photoheterotrophic heterogeneous and 


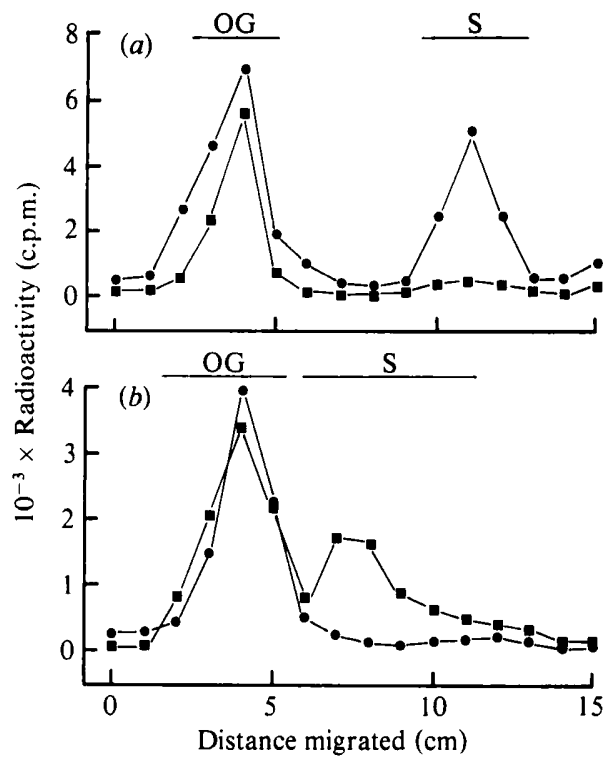

Fig. 1. Incorporation of radioactivity from $2-0 x 0[5-14 \mathrm{C}]$ glutarate into other organic acids. Onedimensional paper chromatograms were run as described in the text and cut into $1 \mathrm{~cm}$ strips. The results are liquid scintillation count data along individual tracks corrected for background activity. The positions of standard organic acids are marked: OG, 2-oxoglutarate; S, succinate. (a) E. coli lysate $\left(7.7 \mathrm{mg} \mathrm{ml}^{-1}\right.$ protein), $30 \mathrm{~min}$ incubation period (O); $R \mathrm{~m}$. vannielii photoheterotrophic lysate (7.9 $\mathrm{mg} \mathrm{ml}^{-1}$ protein), $30 \mathrm{~min}$ incubation period ( $\square$ ). (b) $R m$. vannielii chemoheterotrophic lysate $\left(4 \mathrm{mg} \mathrm{ml}^{-1}\right.$ protein) with samples taken at $0 \mathrm{~h}(\mathrm{O})$ and after $2 \mathrm{~h}$ incubation $(\square)$.

synchronous swarmer cell populations are given in Table 2. At no time was there any detectable difference in activity between cell-free extracts prepared by sonication and the French pressure cell. 2-Oxoglutarate dehydrogenase activity was virtually undetectable in such cultures but significant activity [about $43 \mathrm{nmol} \mathrm{\textrm {min } ^ { - 1 }}$ (mg protein $)^{-1}$ ] was found in extracts of microaerophilically grown cells, suggesting the existence of a complete cycle under such conditions. In experiments where 2-oxoglutarate dehydrogenase activity was not detectable in $R m$. vannielii, lysates of aerobically grown $E$. coli $\mathrm{C}$ and $P$. putida contained demonstrable activity and served as positive controls.

Properties of the citrate synthase of Rm. vannielii. The effects of exogenous compounds on the activity of citrate synthase are summarized in Table 3. Significant inhibition by ATP and NADH was observed and the latter inhibition could be reversed by the addition of AMP. No significant reduction in activity was observed in the presence of $10 \mathrm{~mm}$-2-oxoglutarate.

Utilization of $2-o x o\left[5-{ }^{14} \mathrm{C}\right]$ glutarate by cell-free extracts. To complement the enzyme activity data, an assay for the conversion of radiolabelled 2-oxoglutarate into succinate was used. The distribution of radioactivity along the chromatograms is illustrated in Fig. 1. No significant conversion of 2-oxoglutarate into succinate could be demonstrated in photoheterotrophic cell lysates of $R m$. vannielii but this was observed with lysates from $E$. coli. However, with extracts derived from chemoheterotrophically grown cells of $R m$. vannielii, a radioactive peak corresponding with the position of succinate (run on the same chromatogram) was detected. The relative position of succinate to 2-oxoglutarate varied somewhat in different separations, but the radioactive peaks always correlated with the position of standard acids when run on the same chromatograms. 


\section{DISCUSSION}

The predominance of acetate-derived carbon in the leucine, glutamine, proline and arginine residues of protein hydrolysates of photoheterotrophically grown $R m$. vannielii (Table 1) is suggestive of the existence of an incomplete TCA cycle under such conditions. Similar labelling patterns have been obtained in a variety of phototrophic, lithotrophic and methylotrophic bacteria (Hoare et al., 1967; Pearce et al., 1969; Smith et al., 1967; Smith \& Hoare, 1977) and in these cases are a result of the operation of an incomplete TCA cycle lacking 2-oxoglutarate dehydrogenase or one exhibiting very low levels of activity of this enzyme. Direct enzyme assays demonstrated the presence of all other enzymes of the TCA cycle but an extremely low level of 2oxoglutarate dehydrogenase (Table 2). The absence of the latter enzyme was confirmed (Fig. 1) by the negligible amount of $2-0 \times 0\left[5-{ }^{14} \mathrm{C}\right]$ glutarate converted to succinate by cell-free extracts of $R m$. vannielii. These results all suggest the existence of a functionally incomplete TCA cycle in this organism under anaerobic conditions.

Under aerobic conditions the presence of 2-oxoglutarate dehydrogenase suggests the operation of a complete TCA cycle. This observation is similar to those made for other members of the Rhodospirillaceae and also for $E$. coli under variable growth conditions (Amarasingham \& Davis, 1965). However, in the other Rhodospirillaceae even under anaerobic photoheterotrophic growth conditions a low but significant level of 2-oxoglutarate dehydrogenase activity is detectable (Beatty \& Gest, $1981 a, b$; Eley et al., 1979; Cox et al., 1983). The various lines of evidence suggest that this is not the case in $R m$. vannielii and that repression of 2-oxoglutarate dehydrogenase synthesis under anaerobic conditions is more complete. However, its response to increasing oxygen levels, the production of higher levels of the enzyme, is identical to that observed in other Rhodospirillaceae (Eley et al., 1979; Cox et al., 1983). Under anaerobic conditions the role of the TCA cycle of $R \mathrm{~m}$. vannielii appears solely biosynthetic in function, as is the case with many autotrophs (Pearce et al., 1969; Weitzman, 1982).

The pattern of inhibitor effects on the $R m$. vannielii citrate synthase (Table 3 ) is similar to those reported for other members of the Rhodospirillaceae (Flechtner \& Hanson, 1970; Weitzman, 1982) and is typical of the results obtained in Gram-negative organisms (ATP and NADH sensitive: Weitzman \& Jones, 1968). However, the absence of inhibition by 2oxoglutarate was considered surprising. It has been proposed (Weitzman \& Dunmore, 1969) that such an inhibition may represent a feedback control process in an incomplete TCA cycle and subsequent observations in autotrophic thiobacilli (Taylor, 1970), Gram-positive facultative anaerobes (Tanaka \& Hanson, 1975) and strict anaerobes (Gottschalk \& Dittbrenner, 1970) support this hypothesis. $R m$. vannielii would appear to be an exception to this pattern of behaviour.

$R m$. vannielii is also unusual in its possession of both NAD- and NADP-linked isocitrate dehydrogenase activity. The vast majority of bacteria exhibit only NADP-linked activity, NAD-linked activity having been detected in a restricted yet disparate group of organisms, for example Xanthomonas pruni (Ragland et al., 1966), Acetobacter aceti, Gluconobacter suboxydans (Greenfield \& Claus, 1969), Rhizobium sp. (Moustafa \& Leong, 1975), some thiobacilli (Matin \& Rittenberg, 1971) and a number of methylotrophs (Colby \& Zatman, 1975). The functional role of the two systems is as yet unclear, for although Tabita \& Lundgren (1971) demonstrated that Thiobacillus ferrooxidans utilized NADP-linked isocitrate dehydrogenase during aerobic, heterotrophic growth and NAD-linked activity under anaerobic conditions in an incomplete TCA cycle, such an explanation does not follow for $R m$. vannielii which possesses both enzymes under all growth conditions (D. J. Kelly, P. Morgan \& C. S. Dow, unpublished) nor for many of the other organisms cited above.

The absence of significant differences in enzyme activity and inhibitor patterns between heterogeneous and swarmer cell populations of $R m$. vannielii suggests that the 'shut down' nature of the swarmer cell (Dow et al., 1983) does not involve direct alteration of enzyme activities of the TCA cycle. Whether such effects in vivo are undetectable in crude assays of activity and whether such effects would be detectable in organisms possessing a complete TCA cycle is unclear. In the former case it is certainly possible for in vivo levels of inhibitors to have an effect which is undetectable in these experiments. It is possible that significant effects on such 
important routes of intermediary metabolism as the TCA cycle in the different cell types of prosthecate bacteria would be counter-productive if, as we have proposed, the physiological and ecological roles of swarmer cells (Dow et al., 1983; Morgan \& Dow, 1986) in situ necessitate a rapid response to changing environmental conditions.

The research described in this paper was funded by studentships from the Natural Environment Research Council (P.M.) and the Science and Engineering Research Council (D. J.K).

\section{REFERENCES}

Amarasingham, C. R. \& Davis, B. D. (1965). Regulation of $\alpha$-ketoglutarate dehydrogenase formation in Escherichia coli. Journal of Biological Chemistry 240, 3664-3668.

BEATTY, J. T. \& GEST, H. (1981a). Generation of succinyl-coenzyme $\mathrm{A}$ in photosynthetic bacteria. Archives of Microbiology 129, 335-340.

BeatTy, J. T. \& GeST, H. (1981 $b$ ). Biosynthetic and bioenergetic functions of citric acid cycle reactions in Rhodopseudomonas capsulata. Journal of Bacteriology 148, 584-593.

CHA, S. (1969). Succinate thiokinase from pig heart. Methods in Enzymology 13, 62-69.

Colby, J. \& Zatman, L. J. (1975). Tricarboxylic acid cycle and related enzymes in restricted facultative methylotrophs. Biochemical Journal 148, 505-511.

CoX, J. C., Beatty, J. T. \& Favinger, J. L. (1983). Increased activity of respiratory enzymes from photosynthetically grown Rhodopseudomonas capsulata in response to small amounts of oxygen. Archives of Microbiology 134, 324-328.

Dow, C. S. \& France, A. D. (1980). Simplified vegetative cell cycle of Rhodomicrobium vannielii. Journal of General Microbiology 117, 47-55.

Dow, C. S., Whittenbury, R. \& CarR, N. G. (1983). The 'shut down' or 'growth precursor' cell - an adaptation for survival in a potentially hostile environment. In Microbes in Their Natural Environments, pp. 187-247. Edited by J. H. Slater, R. Whittenbury \& J. W. T. Wimpenny. Cambridge: Cambridge University Press.

Duchow, E. \& Douglas, H. C. (1949). Rhodomicrobium vannielii, a new photoheterotrophic bacterium. Journal of Bacteriology 58, 407-416.

Eley, J. H., KNobloch, K. \& HaN, T.-W. (1979). Effect of growth condition on enzymes of the citric acid cycle and the glyoxylate cycle in the photosynthetic bacterium Rhodopseudomonas palustris. Antonie van Leeuwenhoek 45, 521-529.

FlechtNeR, V. R. \& Hanson, R. S. (1970). Regulation of the tricarboxylic acid cycle in bacteria. A comparison of citrate synthases from different bacteria. Biochimica et biophysica acta 222, 253 264.

Gottschalk, G. \& Dittbrenner, S. (1970). Properties of (R)-citrate synthase from Clostridium acidi-urici. Hoppe-Seyler's Zeitschrift für physiologische Chemie 351, 1183-1190.

Greenfield, S. \& Claus, G. W. (1969). Isocitrate dehydrogenase and glutamate synthesis in Acetobacter suboxydans. Journal of Bacteriology 100, 12641270.

Herbert, D., Phipps, P. J. \& Strange, R. E. (1971). Chemical analysis of microbial cells. Methods in Microbiology 5B, 209-344.
Hoare, D. S., Hoare, S. L. \& Moore, R. B. (1967). The photoassimilation of organic compounds by autotrophic blue-green algae. Journal of General Microbiology 49, 351-370.

Kelly, D. J. \& Dow, C. S. (1984). Microbial differentiation: the role of cellular asymmetry. Microbiological Sciences 1, 214-219.

KING, T. E. (1963). Reconstitution of respiratory chain enzyme systems. XI. Use of artificial electron acceptors in the assay of succinate dehydrogenating enzymes. Journal of Biological Chemistry 238, 40324036.

LARK, K. G., Repko, T. \& Hoffman, E. J. (1963). The effect of amino-acid deprivation on subsequent deoxyribonucleic acid replication. Biochimica et biophysica acta 76, 9-24.

Matin, A. \& Rittenberg, S. C. (1971). Enzymes of carbohydrate metabolism in Thiobacillus species. Journal of Bacteriology 107, 179-186.

Morgan, P. \& Dow, C. S. (1986). Environmental control of cell type expression in prosthecate bacteria. In Bacteria in Their Natural Environments, pp. 131-169. Edited by M. Fletcher \& G. D. Floodgate. London: Academic Press.

Moustafa, E. \& Leong, C. K. (1975). Effect of adenine nucleotides on NAD-dependent isocitrate dehydrogenases in rhizobia and bacteroids of legume root nodules. Biochimica et biophysica acta 391, 9-14.

Pearce, J., Leach, C. K. \& CarR, N. G. (1969). The incomplete tricarboxylic acid cycle in the blue-green alga Anabaena variabilis. Journal of General Microbiology 55, 371-378.

Potrs, L. E. \& Dow, C. S. (1979). Nucleic acid synthesis during the developmental cycle of the Rhodomicrobium vannielii swarm cell. FEMS Microbiology Letters 6, 393-395.

Ragland, T. E., Kawasaki, T. \& Lowenstein, J. M. (1966). Comparative aspects of some bacterial dehydrogenases and transhydrogenases. Journal of Bacteriology 91, 236-244.

REeVES, H. C., RABIN, R., Wegener, W.S. \& AJL, S. J. (1971). Assay of enzymes of the tricarboxylic acid and glyoxylate cycles. Methods in Microbiology 6A, 425-462.

Smith, A. J. \& HoARE, D. S. (1977). Specialist phototrophs, lithotrophs and methylotrophs: a unity among a diversity of procaryotes? Bacteriological Reviews 41, 419-448.

Smith, A. J., London, J. \& Stanier, R. Y. (1967). Biochemical basis of obligate autotrophy in bluegreen algae and thiobacilli. Journal of Bacteriology 94, 972-983.

Suissa, M. (1983). Spectrophotometric quantitation of silver grains eluted from autoradiograms. Analytical Biochemistry 133, 511-514. 
TABITA, R. \& LUNDGREN, D. G. (1971). Heterotrophic metabolism of the chemolithotroph Thiobacillus ferrooxidans. Journal of Bacteriology 108, 334-342.

Tanaka, N. \& Hanson, R. S. (1975). Regulation of the tricarboxylic acid cycle in Gram-positive facultatively anaerobic bacilli. Journal of Bacteriology 122, 215-223.

TAYLOR, B. F. (1970). Regulation of citrate synthase activity in strict and facultatively autotrophic thiobacilli. Biochemical and Biophysical Research Communications 40, 957-963.

WEITZMAN, P. D. J. (1982). Unity and diversity in some bacterial citric acid cycle enzymes. Advances in Microbial Physiology 22, 185-244.

Weitzman, P. D. J. \& Dunmore, P. (1969). Regulation of citrate synthase by $\alpha$-ketoglutarate. Metabolic and taxonomic significance. FEBS Letters 3, 265-267.

Weitzman, P. D. J. \& Jones, D. (1968). Regulation of citrate synthase and microbial taxonomy. Nature, London 219, 270-272.

Whittenbury, R. \& Dow, C. S. (1977). Morphogenesis and differentiation in Rhodomicrobium iannielii and other budding and prosthecate bacteria. Bacteriological Review's 41, 754-808. 